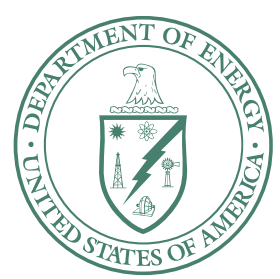

U.S. Department of Energy

Idaho Operations Office

\title{
Site Cleanup Report for Sites PBF-33 and PBF-34
}

January 2007 

DOE/ID-11307

Revision 0

Project No. 23037

\section{Site Cleanup Report for Sites PBF-33 and PBF-34}

January 2007

Prepared for the

U.S. Department of Energy

DOE Idaho Operations Office 



\begin{abstract}
This document summarizes the actions taken to remove asbestosreinforced-concrete (transite) pipe and miscellaneous debris from Power Burst Facility (PBF)-33 and PBF-34 sites. Removal of pipe and debris were performed in November 2006 in accordance with the requirements discussed in notice of soil disturbance NSD-PBF-07-01. Debris at these two sites was classified as industrial waste that could be disposed at the Central Facilities Area (CFA) landfill at the Idaho National Laboratory. Asbestos removal was performed as Class IV asbestos cleanup work. All transite pipe was double bagged and dispositioned in the INL Landfill Complex at CFA. The remaining miscellaneous debris was loaded into dump trucks and taken to the INL Landfill Complex at CFA for final disposition. Cleanup actions are complete for both sites, and no debris or hazardous constituents remain. Therefore, both sites will be classified as No Action sites.
\end{abstract}




\section{CONTENTS}

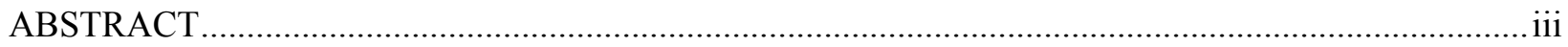

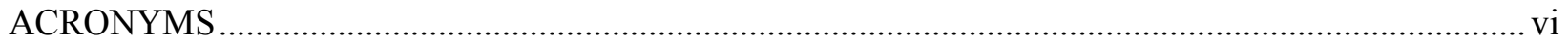

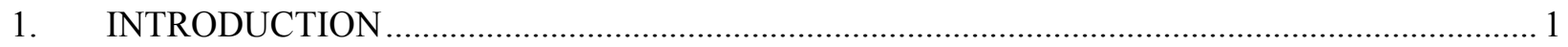

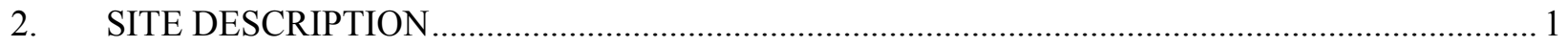

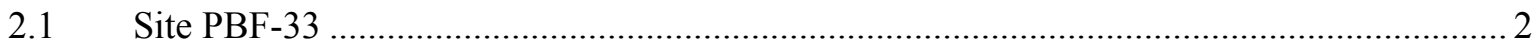

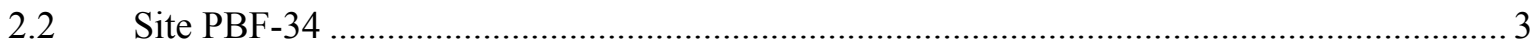

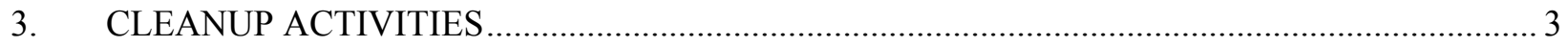

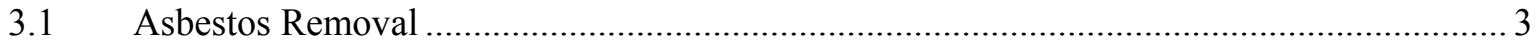

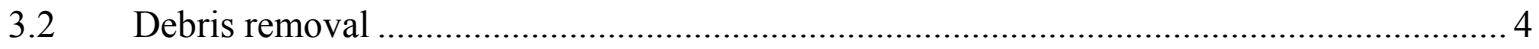

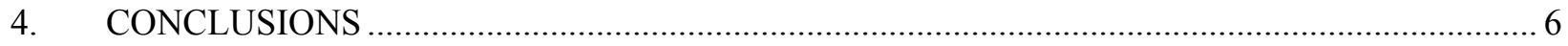

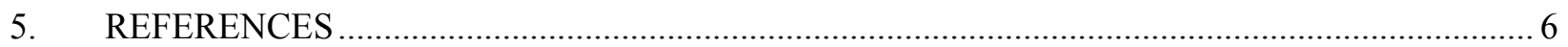

FIGURES

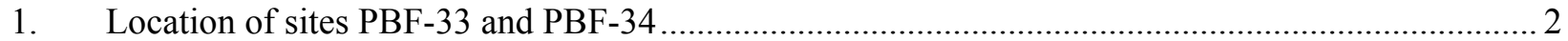

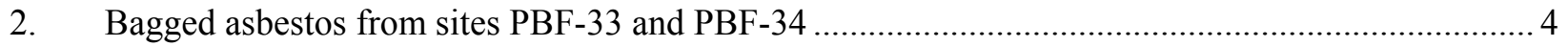

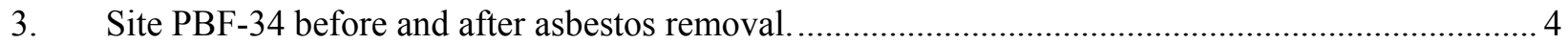

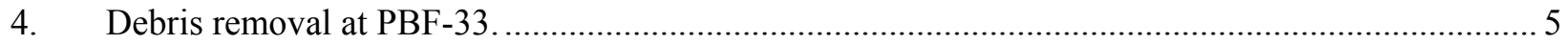

5. Site PBF-33 before and after cleanup activities. ….................................................................. 5 


\section{ACRONYMS}

CFA Central Facilities Area

EPA Environmental Protection Agency

INL Idaho National Laboratory

MWSF Mixed Waste Storage Facility

PBF Power Burst Facility

SPERT Special Power Excursion Reactor Test 


\section{Site Cleanup Report for Sites PBF-33 and PBF-34 \\ 1. INTRODUCTION}

The purpose of this document is to summarize the actions that were taken to remove and dispose of miscellaneous debris and asbestos-reinforced concrete (transite) pipe and pipe fragments from Power Burst Facility (PBF)-33, and PBF-34 sites at the Idaho National Laboratory (INL). These two sites were discovered in November 2000 and identified as Comprehensive Environmental Response, Compensation, and Liability Act (CERCLA) sites through the new site identification process in March 2001 (Document No. 10928 and No. 10929). Because they were identified after the signature of the Record of Decision for PBF and the Auxiliary Reactor Area, they were included in the Federal Facility Agreement and Consent Order as CERCLA sites in Operable Unit 10-08. Both sites were further investigated under the Track 1 investigation processes and determined to be No Action sites. However, the Track 1 decision statement by the Remediation Project Mangers for both the EPA and DEQ identified that asbestos and other hazardous constituents should be removed and appropriately dispositioned prior to finalization of a No Action determination for these sites (DOE-ID 2006 and 2006a).

\section{SITE DESCRIPTION}

Sites PBF-33 and PBF-34 are both located in close proximity to building PBF-613 (Figure 1). Building PBF-613 originally housed the Special Power Excursion Reactor Test (SPERT) -IV reactor, which was operational from 1961 to 1970 . Following completion of the SPERT-IV experiments, the reactor was removed in 1979, and the building was modified slightly and converted to a waste storage facility. The building was closed in 2004 and is no longer actively used. 


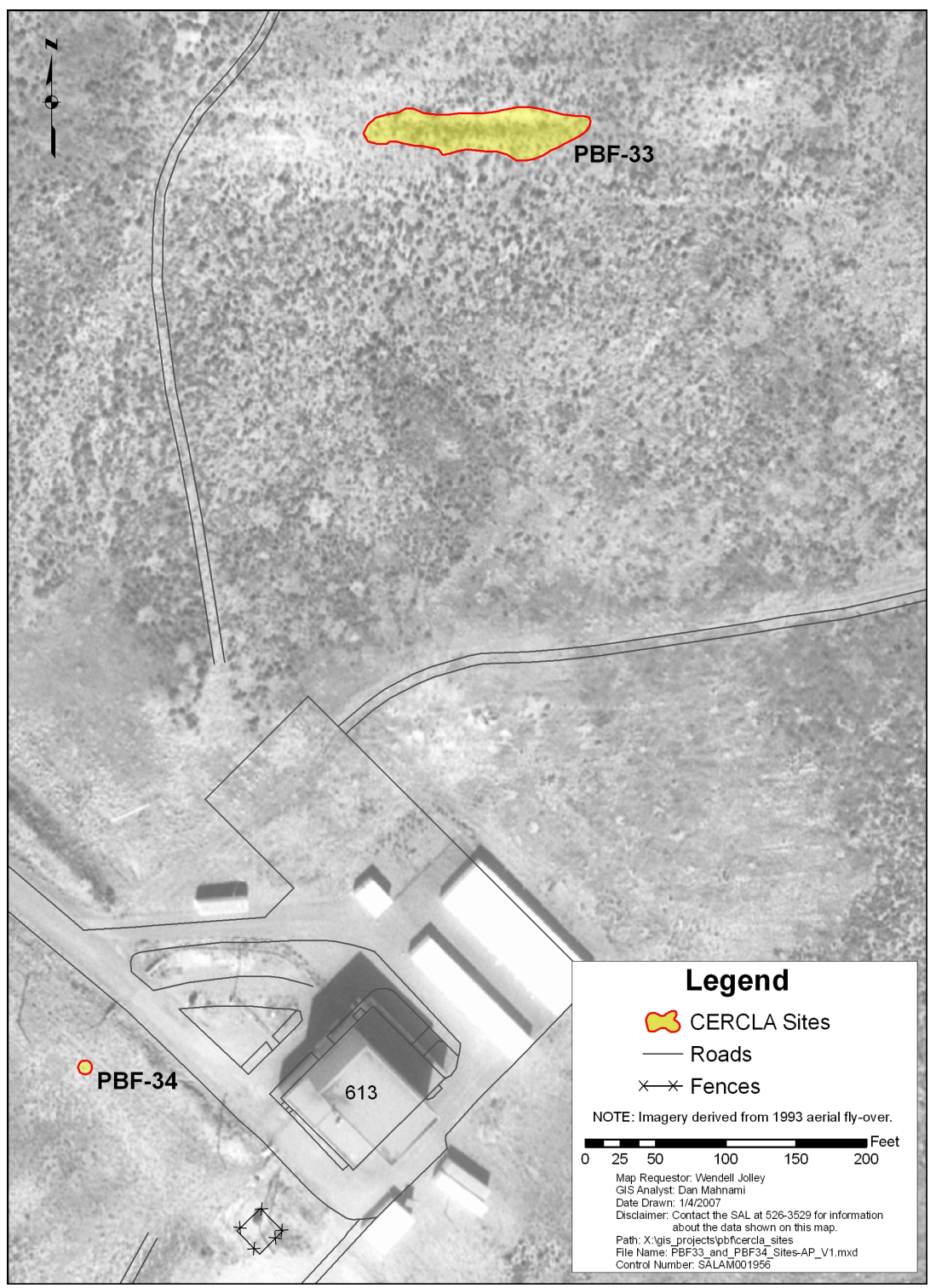

Figure 1. Location of sites PBF-33 and PBF-34.

\subsection{Site PBF-33}

Site PBF-33 was a small debris-filled trench about 200 yards north of the Mixed Waste Storage Facility (MWSF) in the PBF area. Dimensions of the trench are approximately $160 \mathrm{ft} \times 10 \mathrm{ft} \times 5 \mathrm{ft}$, and the debris consisted mainly of construction materials including broken concrete slabs and blocks, metal piping, empty 55-gal drums, empty gasoline cans, metal wire, tires, wood, and other miscellaneous scrap. The age and source of the debris is unknown, but it was likely abandoned by the SPERT-IV facility during construction/operation, or during the removal of the reactor from the building. Based on weathering and deterioration of the debris, materials are estimated to be several decades old, which approximates the timeframe in which the facility was in operation.

Trench debris also included weathered lengths of transite piping. As part of the new site identification, the transite material was analyzed by polarized light microscopy with dispersion staining per standard operating procedure SOP-IHL-2.01, similar to National Institute for Occupational Safety and 
Health (NIOSH) 9002, and Environmental Protection Agency (EPA) method 600/M4-82-020, to verify the presence of asbestos. The material was also determined by an EPA-certified asbestos inspector at the INL to be friable. This determination was made in accordance with 40 Code of Federal Regulation (CFR) 61.141 by application of hand/finger pressure to pulverize the material. Although transite pipe is not generally considered to be friable, exposure to the elements weathered the pipe such that it can be pulverized by application of normal hand pressure.

Additional analysis included a radiological survey of the asbestos material and approximately $20 \%$ of the other items. All the direct beta/gamma scans were $<100$ counts per minute (cpm) above background, and all alpha scans were equal to background. The resulting decision from the Track 1 investigation of the site was that the trench was used as a dumpsite for industrial waste, and the debris should be removed and properly disposed, but no additional investigation is necessary.

\subsection{Site PBF-34}

Site PBF-34 consisted of a small volume of transite pipe fragments laying on the ground surface about $150 \mathrm{ft}$ west of MWSF. The pipe debris was scattered in an area approximately $6 \mathrm{ft} \times 6 \mathrm{ft}$. The pipe material was determined by an EPA-certified asbestos inspector at the INL to be nonfriable. This determination was made in accordance with CFR 61.141. A radiological survey was performed on the asbestos, and all direct beta/gamma scans were $<100$ counts per minute above background, with no detectable alpha contamination. The Track 1 investigation determined that this site does not pose a risk to human health; however, the debris should be removed from the site and disposed at an appropriate landfill.

\section{CLEANUP ACTIVITIES}

Debris from sites PBF-33 and PBF-34 was removed in two phases. Transite material was removed first, followed by the removal and disposal of the remainder of the debris.

\subsection{Asbestos Removal}

Removal of asbestos material from both sites was performed as Class IV asbestos cleanup work on November 16,2006. Asbestos material was wetted and removed, placed in plastic bags, and sealed prior to disposal at the INL Landfill Complex at the CFA (Figure 2). A total of four bags (less than $0.5 \mathrm{yd}^{3}$ ) of transite material were removed from the sites. The bags were labeled with asbestos warning labels and deposited in the INL Landfill Complex at CFA. 


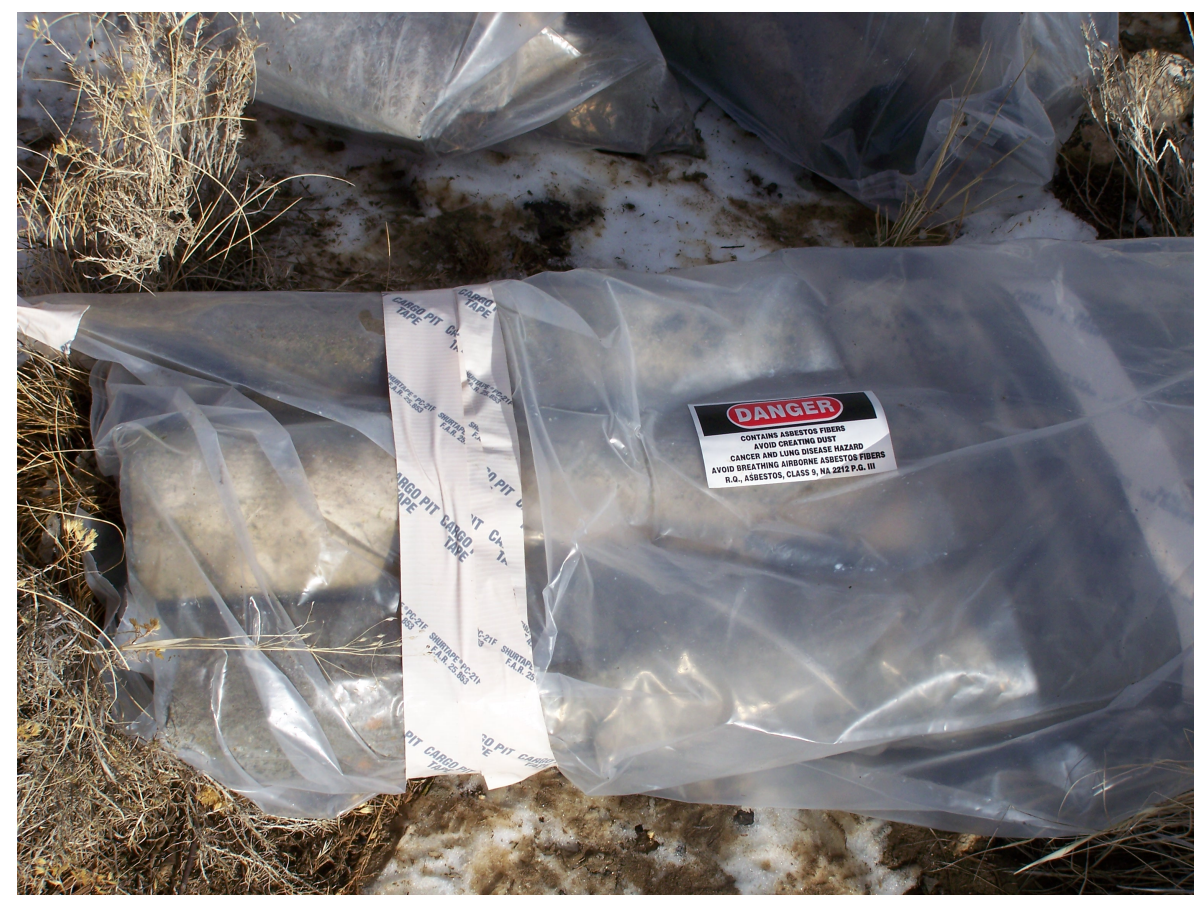

Figure 2. Bagged asbestos from sites PBF-33 and PBF-34.

Site PBF-34 consisted only of the transite pipe fragments. Following removal of the transite pipe fragments, the site is clean; therefore no additional cleanup efforts are necessary. Figure 3 shows the site prior to and following the asbestos removal efforts.
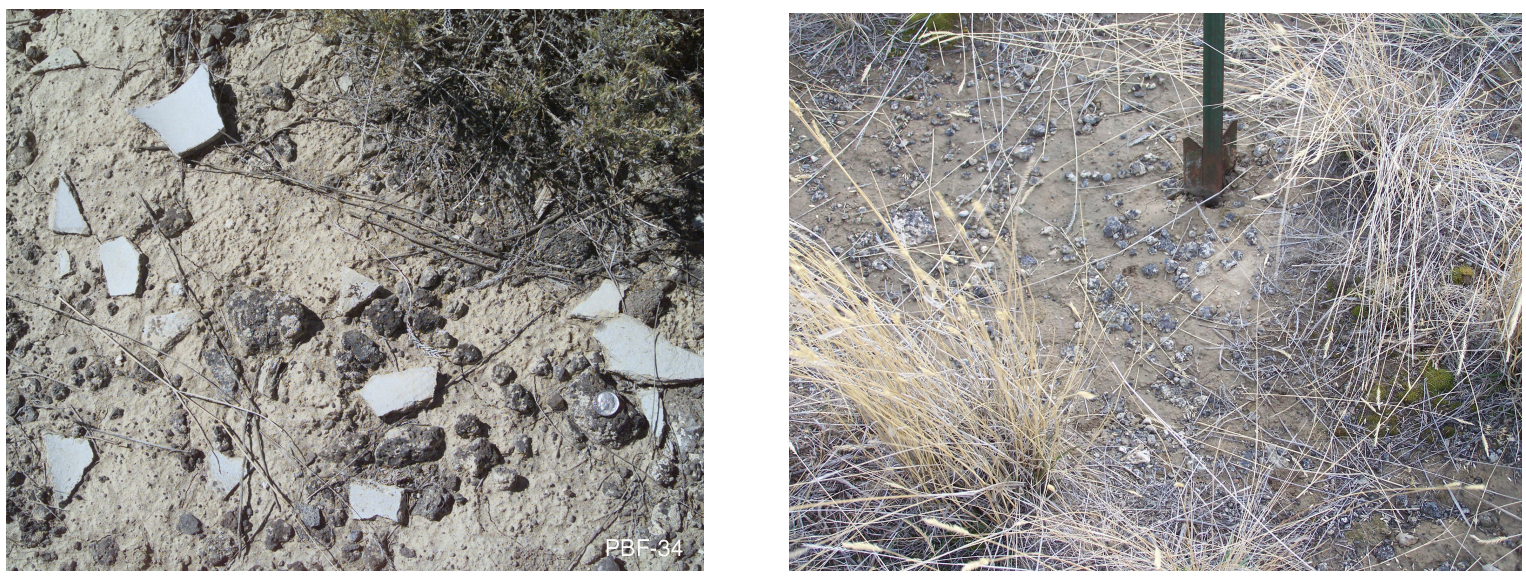

Figure 3. Site PBF-34 before and after asbestos removal.

\subsection{Debris Removal}

Following the removal of asbestos material from site PBF-33, the remaining miscellaneous debris was removed on November 20, 2006. Using a track-hoe, the debris was pulled from within the trench and piled at the edge (Figure 4). A front-end loader picked up the debris and loaded it into dump trucks that transported it to the INL Landfill Complex at CFA. A radiological controls technician performed direct beta/gamma scans on the debris as it was removed from the trench. All of the scans were $<100$ counts per minute above background. 


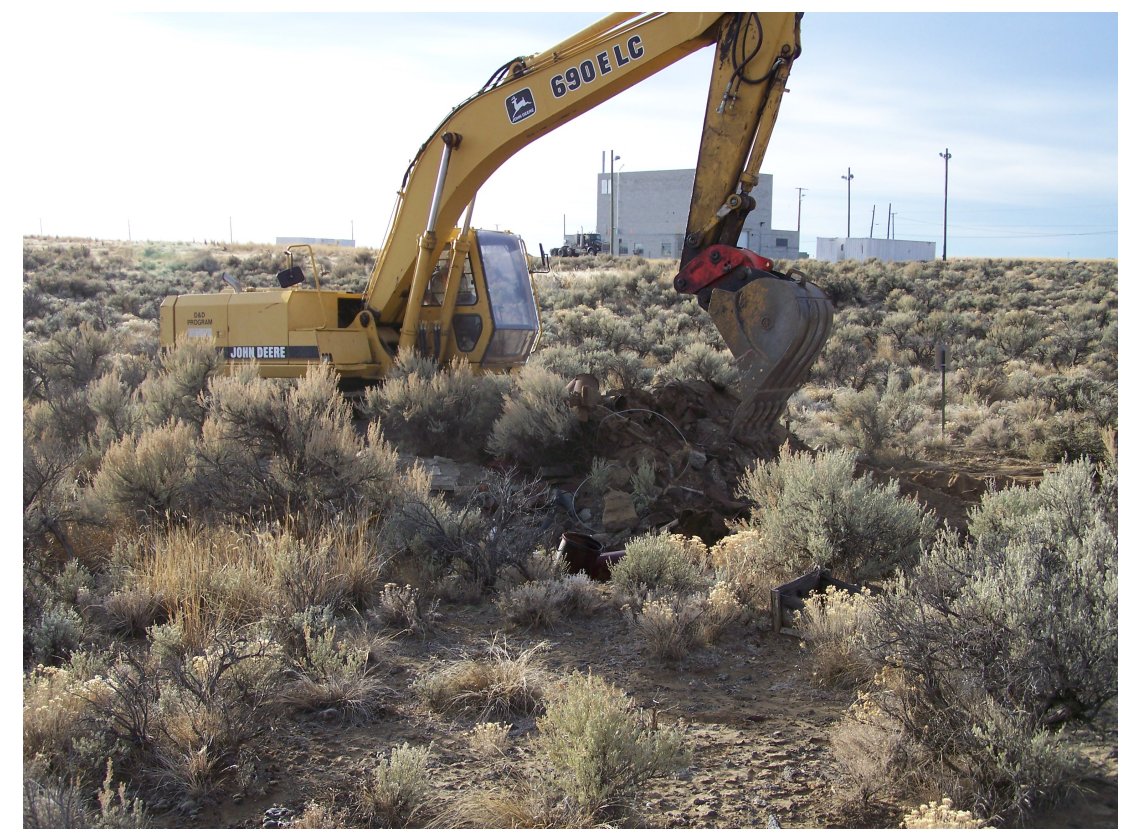

Figure 4. Debris removal at PBF-33.

A total of six truck loads (approximately $75 \mathrm{yd}^{3}$ ) of debris were removed from site PBF-33. The debris was limited to the surface and there is no evidence of additional debris or contamination at this site. Therefore, no further cleanup work is required. Figure 5 shows site PBF-33 before and after cleanup actions were completed.
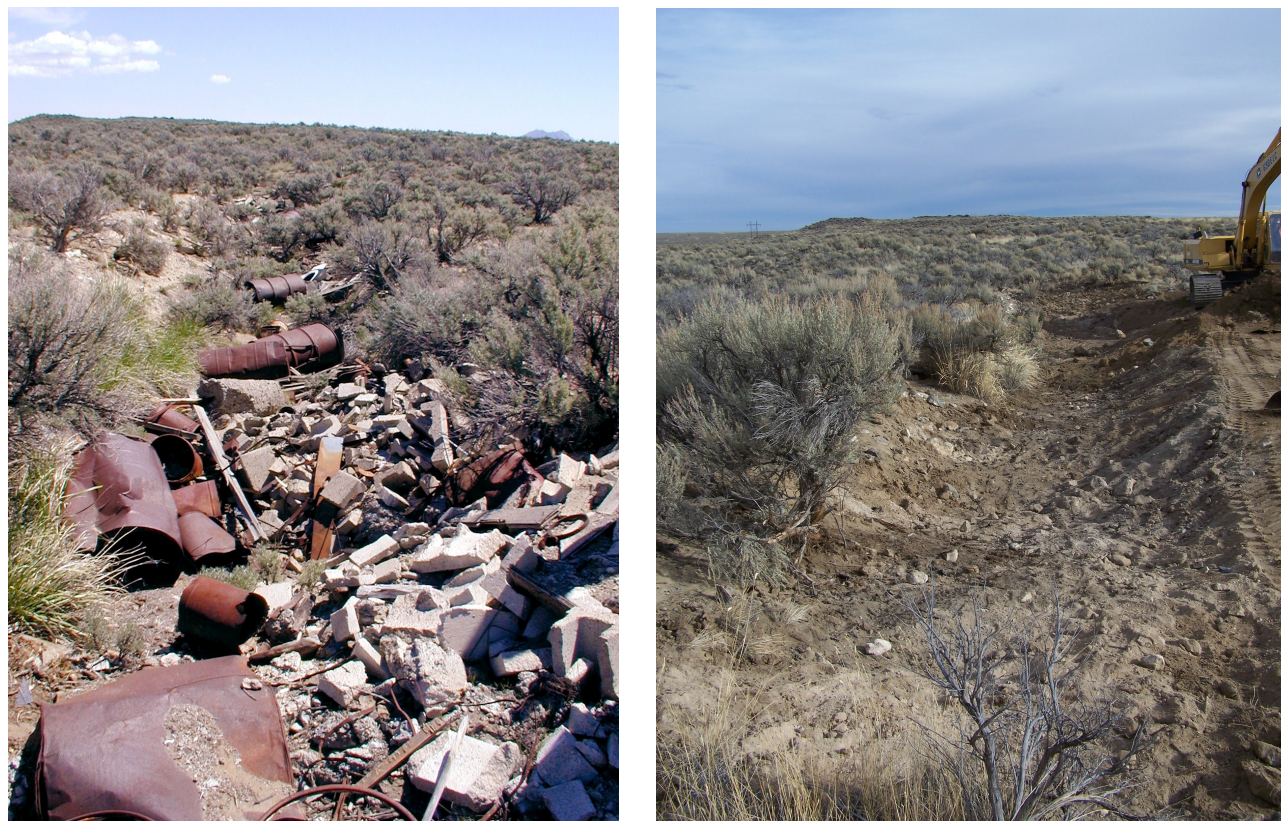

Figure 5. Site PBF-33 before and after cleanup activities. 


\section{CONCLUSIONS}

In accordance with the recommendations by the agencies' Remediation Project Mangers in the Track 1 decision statements for sites PBF-33 and PBF-34, the debris from both sites was removed and deposited at INL Landfill Complex at CFA. No debris or hazardous constituents remain at either site; therefore, both sites will now be classified as No Action sites. At the time these sites were discovered, warning signs were installed to restrict access to the sites. With the completion of the removal actions at these sites, there is no longer a need to restrict access to the sites so the signs will be removed following agency concurrence with this report.

Because the soil and vegetation at site PBF-34 was undisturbed by the cleanup actions, no revegetation will be necessary. However, use of heavy equipment at site PBF-33 resulted in some disturbance to the soil and surrounding vegetation. Consequently, the area will be reseeded in early spring 2007.

\section{REFERENCES}

Document No. 10928, "New Site Identification (NSI) - Operable Unit (OU) 10-08 Power Burst Facility 33 (PBF-33) - Abandoned Debris Trench," Department of Energy, Environmental Protection Agency, and Idaho Department of Health and Welfare, March 13, 2001.

Document No. 10929, "New Site Identification (NSI) - Operable Unit (OU) 10-08 Power Burst Facility 34 (PBF-34) - Abandoned Debris Located Near the Mixed Waste Storage Facility (MWSF)," Department of Energy, Environmental Protection Agency, and Idaho Department of Health and Welfare, March 13, 2001.

DOE-ID, 2006, Track 1 Decision Documentation Package - Abandoned Debris Trench - Power Burst Facility 33 (PBF-33), Operable Unit 10-08 (OU 10-08), DOE/ID-10988, U.S Department of Energy Idaho Operations Office, March 22, 2006.

DOE-ID, 2006a, No Action Site - Track 1 Decision Documentation Package - Abandoned Debris Located Near the Mixed Waste Storage Facility (MWSF) - Operable Unit (OU) 10-08 Power Burst Facility (PBF-34), DOE/ID-10989, U.S Department of Energy Idaho Operations Office, June 8, 2006. 